\title{
Influence of Transformational Leadership on Employees' Innovative Work Behavior in Sustainable Organizations: Test of Mediation and Moderation Processes
}

\author{
Hui Li ${ }^{1,2}$, Nazir Sajjad ${ }^{1, *(\mathbb{D}}$, Qun Wang ${ }^{1,2}$, Asadullah Muhammad Ali ${ }^{3,4}\left(\mathbb{D}\right.$, Zeb Khaqan ${ }^{5}$ and \\ Shafi Amina ${ }^{1}$ \\ 1 Department of Management and HR, Business School, Hohai University, Nanjing 211100, China; \\ lhui@hhu.edu.cn (H.L.); wqun@hhu.edu.cn (Q.W.); aminasajjad@hotmail.co.uk (S.A.) \\ 2 Jiangsu Provincial Collaborative Center of World Water Valley and Water Ecological Civilization, \\ Nanjing 211100, China \\ 3 Department of Human Resource Management, Emirates College of Technology, Abu Dhabi 41009, UAE; \\ iae.hec@gmail.com \\ 4 Lahore Business School (LBS), University of Lahore, Lahore 53700, Pakistan \\ 5 Department of Management Sciences, Ghulam Ishaq Khan Institute of Engineering, Science and Technology, \\ Topi. Swabi. KPK. 23640, Pakistan; zkhaqan@gmail.com \\ * Correspondence: sajjadnazir@hotmail.com
}

Received: 31 January 2019; Accepted: 4 March 2019; Published: 15 March 2019

\begin{abstract}
The main objective of this research was to examine how transformational leaders boost their followers' innovative work behavior through trust in a leader, empowerment, and work engagement. Data were collected from 281 multinational organization employees in China. The Statistical Package for the Social Sciences (SPSS) macro process was utilized to test the proposed hypothesis. The findings revealed that transformational leadership and work engagement were significantly related to innovative work behavior. The findings also demonstrated the significant impact of transformational leadership on trust in a leader, and its subsequent positive impact on the work engagement of the employees. Furthermore, the results supported a significant serial mediation between transformational leadership, trust, work engagement, and employees' innovative behavior. The results also showed a significant moderating effect of empowerment on transformational leadership and innovative work behavior. For boosting employees' innovative work behavior, leaders in the organization should strive to engage them effectively in their work by gaining their trust, which could help them participate in creative activities. This is the key study to investigate the different perspectives of how transformational leadership can stimulate followers' innovative behavior through trust in the leader and work engagement within the Chinese organizational context.
\end{abstract}

Keywords: transformational leadership; trust in leader; empowerment; work engagement; innovative work behavior

\section{Introduction}

Human performance is one of the triple bottom line dimensions, alongside the economic and environmental dimensions, which organizations today are striving to achieve in order to ensure organizational sustainability [1,2]. Unfortunately, the human dimension has received a limited consideration in the organizational literature on organizational sustainability, as compared to the environmental and economic dimensions of organizational sustainability [2,3]. However, the significant financial implications of various employees' work-related behaviors call for more significant attention 
toward the human dimension of sustainability. Consequently, the consideration of management scholars and practitioners toward the human dimensions of organizational sustainability has been increasing in the last decade. Innovative work behavior (IWB) is an important employee outcome that is related to the human dimension of organizational sustainability.

Innovative work behavior (IWB) is an important factor that management scholars need to consider, significantly, in order to gain a competitive advantage [4] and establish organizational sustainability. Apart from research and development, the organizations operating in the highly competitive business environment also need innovative work behavior in other domains of businesses [5-7], in order to discover new ways of satisfying customer demands [8-10], and retain their competitive position in the business world [11]. Since the organizations rely on different actors to stimulate innovative work behavior [4], the organizational leaders are the most prominent actors who can foster innovative work behavior at the workplace, and thus bring new changes to an elusive situation [12-15]. Hence, current research has highlighted leadership among the significant factors that influence innovative work behavior [16]. Thus, organizations have realized the need to engage leaders who have the ability to address complex problems with innovative solutions [17].

The current economic and business changes in East Asia require business leaders to use the transformational leadership (TL) style for encouraging innovative work behavior among their employees in order to achieve sustainable economic growth [18,19]. Transformational leadership has captured the attention of leading researchers, who have investigated the antecedents of innovative behavior in the existing stream of literature on innovative work behavior [10,20-27]. Transformation leadership refers to the leaders who develop their followers' potential for work through inspiration, intellectual stimulation, and empowerment, which might help develop innovative work behavior [28-30]. The transformational leaders are more likely to encourage innovative work behavior, as they directly influence the creativity and performance of their followers [31], by empowering them and fostering trust and engagement in them [32-34].

Along with the consequences of transformational leadership, the existing research has also reported empowerment [35-37], work engagement [38], and trust [39,40] as significant predictors of innovative work behavior. Engagement is an outcome of transformational leadership that keeps employees engaged in their work and facilitates them to induce innovative behavior [35]. Similarly, trust contributes to the organizational success [41] by allowing interdependence [42] among employees when performing complex organizational tasks and resolving conflicts [43]. Thus, to foster innovative work behavior among employees, organizational leaders need to consider the trust in leaders and work engagement as the most important factors linking transformational leadership and innovative work behavior.

Recognizing the role of transformational leadership in innovative work behavior through different positive employee behaviors, the current research offers its theoretical contribution to the existing research on innovative work behavior in two important aspects. First, this study proposed and tested a serial mediation mechanism to explain how trust and work engagement strengthen the relationship between transformational leadership and innovative work behavior. Whereas our second contribution is to investigate situations where empowerment moderates the relationship between transformational leadership and innovative work behavior.

\section{Theory and Hypotheses}

Transformational leadership is a unique leadership style, which is theorized to have the ability to influence employees' moral values and ethics in such a way that they tend to perform better than expected $[24,44]$. Transformational leadership extensively focuses on the consideration, intellectual stimulation, and inspirational motivation of the individuals [24,45]. Moreover, transformational leaders are considered more trustworthy, realistic, and practical, which could help them to accomplish their tasks and also has the potential to stimulate innovative work behavior [28,34]. Innovation is described as the process that enables the individual to develop and implement new ideas to perform better 
in their job [46,47]. Innovation is considered to be a multi-step process that involves the individual ability to recognize a problem, generate novel ideas, and have the ability to support and implement these ideas [19,48]. Innovation is not only influenced by organizational factors, but also by motivation, organizational support, and the personality of the individual [49].

\section{Social Exchange Theory (SET)}

The social exchange theory explains how transformational leaders may affect employee engagement through social exchanges by creating a friendly and trustworthy environment [50] that is based on trust and an "open-ended stream of transactions" [51], with economic exchanges and contractual obligations, in particular (p. 162). The social exchange theory has the basic principle that followers of transformational leaders will pay back their supportive leaders by demonstrating positive behaviors and attitudes, which contribute positively to an organization, for example, organization commitment, job satisfaction, organizational citizenship behavior work performance, and innovative work behavior [27,52-54]. Saks (2006) [55] integrated engagement in beneficial exchange relationships, stating that, "Bringing oneself more fully into one's work roles and devoting greater amounts of cognitive, emotional, and physical resources is a very profound way for individuals to respond to an organization's actions" (p. 603). Moreover, transformational leaders have the ability to stimulate higher levels of employee engagement by creating a comfortable and trustworthy environment in the organization [56].

However, Blau (1964) [50] proposed the SET based on [57] the norms of the reciprocity theory, which is the origin of SET in a sociological context. SET in the environment of an organization has the principle that employees might feel obliged toward their supervisor, coworker, or organization if they have received any benefit from an exchange with the individual or the organization in the past [50]. Two or more people can initiate a social exchange relationship within the organization [58]. When an individual realizes that other individuals have received more benefits from an exchange and the benefits are not mutually shared within a suitable time, as realized by the individual who contributed the social benefit, it may have a negative impact on the workplace environment and the relations between employees [59-61]. Such types of issues with workplace relationships have been revealed to be a major and significant problem in the organizations, because social exchange is not governed by any rules or regulations; rather, they are dependent on the culture, organization environment, and perception of the individuals involved in the exchange [62], which means that every individual involved in the social exchange network will have their own perception-which will be different from others-in terms of what is the fair level of exchange for a positive benefit and what is the right time during which to return these benefits [63].

SET can be utilized as a lens for recognizing the potential results when high quality relationships are implanted in the workplace. Moreover, under an effective working environment, employees would receive suitable support from their coworkers, supervisors, and organization; thus, they would reciprocate by doing beneficial activities related to the organization [64]. This greater level of innovative work behavior can be demonstrated by the employees when they perform work in their own way and do tasks beyond their formal job description or usual expectations. An organization's best interests are rooted in effective workplace practices, which are appropriately developed [53] so that employees are able to create a higher level of trust in their leaders and feel empowered enough to help the coworkers and the organization.

\section{Transformational Leadership and Trust in Leaders}

Transformational leaders significantly affects followers' performance [65] because transformational leaders foster an organizational culture characterizing favorable emotions and mutual trust [66]. The researchers [67-69] have highlighted the importance of trust in the leader-follower relationship [70], particularly in encouraging them to perform their job beyond expectations. Although the significant relationship between transformational leadership and trust is 
well recognized in existing research [43,71-75], some researchers [65] still insist on further investigating the relationship between transformational leadership and trust in leaders. This study addressed this concern using the social exchange theory, from the perspective of Tepper et al. [76], who reported trust in a leader as an outcome that belongs to between-person correlates of transformational leadership. Trust represents an interpersonal exchange between two parties [70], representing a voluntary reliance of one party on another party for taking some actions. Therefore, it is sensible to use SET to describe the link between transformational leadership and followers' trust in leaders. Social exchange theory helps us explain the way in which social exchanges strengthen the interpersonal relationship between the leader and their followers, particularly based on reciprocal exchanges [77], which also lays the foundation of the leader-member exchange theory (LMX) [78].

Since each party is involved in a reciprocal exchange relationship, such as that between leader and follower, it brings a distinct resource for the exchange [79]. The leaders are also expected to provide tangible and intangible incentives to their followers to perform their job beyond expectations [79]. Transformational leadership is characterized by four different dimensions [24], "idealized influence, intellectual stimulation, inspirational motivation, and individualized consideration" [29], which can be considered to be intangible forms of resources, and that the transformational leaders can use to foster a mutual trust in their followers. Idealized influence is the ability to motivate followers to trust and recognize the charisma of their leaders and their mission. Inspirational motivation is the capability to express common goals, as well as a clear and convincing vision that motivates followers and boosts positive expectations [80]. Intellectual stimulation is the ability to test followers' expectations, risk-taking, critical thinking, recognizing, and solving problems practically [40], which becomes more apparent when the transformational leaders present themselves as a role model for their followers. Individualized considerations refer to the leader being able to recognize and understand the developmental needs of followers, listen to their concerns, and treat them equally [27]. Considering these key characteristics as the intangible resources, we propose that the leaders engage them with the followers to induce positive reactions from the followers. Similarly, the followers may perceive individualized consideration consistently provided by a transformational leader as a resource to help them meet their specific performance target. Thus, they may feel obliged and may exchange in terms of increased trust in their leaders. According to Liu et al. [81], aspects of transformational leaders are aligned to some antecedents (e.g., integrity, benevolence, care, and consideration) of trust in the leader. In brief, the followers will be more likely to exchange in the form of increased trust in their leaders. Thus, we hypothesized that:

\section{H1. Transformational leadership is positively related to trust in leaders.}

\section{Trust in Leaders and Work Engagement}

Over the decades, work engagement has become significant as a broader concept that includes involvement and self-presence at work [82]. Work engagement is derived from trust, making employees more attached to the organization in a persistent state [83,84]. Macey et al. [85] proposed that work engagement can be enhanced through developing employees' trust in the leader. Moreover, the relationship between trust in the leader and worker engagement can be hypothesized based on social exchange theory. The present study has revealed that trust is an important predictor of various organizational desired discretionary behaviors, including cooperation [86], citizenship behavior [87], commitment [88], and loyalty [89]. This demonstrates that the employees exchange trust in the leader by exhibiting more discretionary behaviors at their workplace. This suggests that the employees are more likely to exchange their contributions in the form of discretionary behavior when they have greater trust in their leaders. The simple explanation for this exchange is that trust in leaders leads employees to focus more on their current job, because they can devote their effort, energy, and time to perform their job efficiently [90] rather than protecting themselves [91] by indulging in behaviors such as lobbying and ingratiation [92]. We can argue that greater trust in leaders provides more time 
and energy to the employees to focus on their existing job. In return, they will be more engaged in their work. The existing literature supported the positive influence of trust in the leader on employees' work engagement $[90,93,94]$. Thus, we hypothesized that:

H2. Trust in a leader has a positive impact on employees' work engagement.

\section{Work Engagement and Innovative Work Behavior}

The successful organizations need to encourage innovative work behavior at the workplace to utilize employee creativity $[46,95,96]$ to cope with the uncertain business environment [12]. Innovative work behavior refers to the creation and implementation of innovative ideas by employees while performing their job to enhance their task performance, group performance, or organizational performance [97]. Despite the continuing interest of management scholars and practitioners in innovation for long-term organizational success [98], the research in innovative work behavior is still in its infancy stage [90]. Work engagement refers to "a positive, fulfilling, work-related state of mind characterized by vigor, dedication, and absorption" [84] (p. 465). Some recent studies have reported a significant impact of work engagement on innovative work behavior [90,99,100]. Using the lens of social exchange theory, we hypothesize that the employees with higher work engagement, dedication, and absorption are more likely to bring new ideas at work [83]. When leaders in the organization provide an effective working environment to employees where they could highly engage themselves in their work, the employees are more likely to bring more innovative ideas to themselves, their team, and their organization [101]. Thus, we hypothesized that:

H3. Work engagement has a positive impact on employees' innovative work behavior.

\section{Transformational Leadership and Innovative Work Behavior}

Transformational leadership plays an important role in transforming the norms and values, which further help the organizational members in enhancing an individual's performance [102,103]. Transformational leadership stimulates the intellectual thinking that encourages employees to think outside of the box, and thus they become more devoted to accomplishing the organizational vision effectively [104]. The transformational leaders also simulate employees' working behaviors [105] that help the individuals enhance their skills and abilities to solve work-based problems [106,107]. For instance, transformational leaders help the employees think outside of the box for making independent decisions without relying on others to strengthen their intellectual power $[65,108]$. Transformational leaders also have the capacity to develop a unique organizational culture that encourages employees toward innovative work behavior (IWB) $[23,101]$. Transformational leadership bears all these key features (e.g., problem-solving, motivational indicators, and performance evaluation), which are required for creating and enhancing the employees' innovative work behavior [109]. Thus, previous empirical evidence revealed a [37,110,111] positive relationship between transformational leadership and innovative work behavior.

H4. Transformational leadership is positively related to employees' innovative work behavior.

\section{Transformational Leadership, Trust in Leader, Work Engagement, and Innovative Work Behavior: Serial Mediation}

Hypothesis $\mathrm{H} 1$ and $\mathrm{H} 2$ together point toward the mediating role of trust in leaders between TL and work engagement. According to social exchange theory, the parties involved in a social exchange process need to maintain a certain level of trust to reciprocate with each other [50]. In the context of a leader-follower relationship, the characteristics of a transformational leadership style represent certain specific behaviors of a leader that develop a higher perception of employees' trust in a leader [43,71-75]. When the employees' trust in the leader is developed, they may find more time, 
energy, and encouragement to focus on their existing job [90] instead of indulging in self-protective behaviors (e.g., lobbying, absenteeism, impression management) which guarantee them psychological safety in case of low trust in the leaders [91]. Consequently, the employees may feel happier, safe, and encouraged to avail more time and energy, and would engage by emphasizing more on their work [112]. This represents a mediation mechanism explaining how transformational leadership is related to work engagement through trust in the leader.

Similarly, hypotheses $\mathrm{H} 2$ and $\mathrm{H} 3$ together point toward a mediating mechanism explaining how trust in leadership is related to innovative work behavior through work engagement. Based on social exchange theory, we contend that the trust in the leader ensures that more time, energy, and encouragement is available to the employees to perform their job more accurately [90]. Similarly, in the case of trust, the employees will feel more psychological safety, which will empower them to engage more in their work [91]. Consequently, they can introduce more innovative ideas because of the more engaging work environment provided by their leaders and organization [83]. Thus, we proposed that work engagement mediates the relationship between trust in a leader and innovative work behavior.

However, the mediating mechanisms proposed in the previous two paragraphs may explain a serial mechanism through which the leadership can boost innovative work behaviors at the workplace. Considering the previous argument based on SET, current research has proposed and tested a chain association between transformation leadership and innovative work behavior through two important positive constructs, i.e. trust in a leaders and work engagement. Based on social exchange theory (SET), we argue that transformational leaders have certain characteristics that instill trust in the leadership among employees [43,71-75], which leads them to feel more engaged in their work $[85,90]$, and consequently, they will exhibit more innovative work behavior at the workplace $[90,99,100]$. Although the relationship between transformational leadership and innovative work behavior may exist, this relationship will be more pronounced if transformational leaders succeed in instilling trust and engagement among the employees at the workplace. Thus, we hypothesized that:

H5. Trust in leaders mediates the positive relationship between transformational leadership and work engagement.

H6. Work engagement mediates the positive relationship between transformational leadership and innovative work behavior.

H7. Work engagement mediates the positive relationship between trust in leaders and innovative work behavior.

H8. The positive relationship between transformational leadership and innovative work behavior is serially mediated through trust in leaders and innovative work behavior.

\section{Empowerment as a Moderator}

Transformational leadership has become the most significant factor in the last two decades because of its influence on employee attitudes such as empowerment [113]. According to [114], empowerment has a combination of four different kinds of feelings: "competence, meaning, impact, and self-determination" (p. 669). Afsar et al. [110] revealed that transformational leadership has a significant influence on psychological empowerment and employee innovative work behavior. Transformational leaders frequently focus on providing support, teamwork, sharing experience, autonomy in decision making, and authorizing the implementation of ideas, which could boost employees' innovative behavior. Consequently, transformational leadership develops an effective working environment where individuals feel knowledgeable, self-managed, capable, and motivated to practice empowerment [115]. Furthermore, employees who have greater empowerment are more proactive because of independent decision making [116]. Thomas and Velthouse [114] proposed that employees become less effective and are not able to fully use their creative potential because of current conventional organizational practices that reduce the perception of helplessness. Therefore, the sense of helplessness can lead to ineffective operations and hinder employee innovative behavior. 
Edmondson [117] recommended that leaders must endeavor, stimulate empowerment, and instill feelings of determination between employees to transform the organizational vision into reality.

Jung and Avolio [118] stated that transformational leaders empower and encourage their followers through individual consideration and stimulating inspiration instead of concentrating on rewards and punishments. When leaders provide autonomy to their followers and develop a participative culture in the organization, then followers ready to accept task and authority toward achieving collective goals for improving organizational performance. Parry and Proctor-Thomson [119] argued that transformational leaders respect, admire, are responsible to others, and also evaluate their followers' performance, which creates a feeling of empowerment. Thus, TL inspires as well as empowers their followers to participate in decision-making processes and perform the job with shared values and unity.

An organization that wants to become innovative must encourage and facilitate its employee to be creative, because individual creativity leads an organization toward success $[46,95,96]$. Therefore, leaders in any organization are highly educated and they have the responsibility of engaging their employees in the cognitive complex task and designing strategies, which creates an effective working environment to motivate subordinates $[120,121]$. Previous studies have concluded that a firm's survival depends on the creativity and innovation of the employees $[23,27,96,122]$. Transformational leaders have the ability to help their employees think outside of the box, which requires not depending on others for the decision they could make, and increase intellectual power $[65,108]$. Furthermore, transformational leaders simulate the working behavior of the individual in such a way that transforms their dedication to organizational success [105]. A unique culture can be promoted by transformational leaders, where employees are challenged to generate and implement new ideas through innovative work behavior [101]. A unique culture in the organization can be established through the capabilities of transformational leaders who compel the employees to push themselves to innovative behavior [23,101]. Consequently, different factors such as intrinsic motivation, problem-solving skills, and performance appraisal are required for creating and enhancing the employees' innovative work behavior [109]. Supporting our view, a previous study revealed that empowerment positively moderates the relationship between transformational leadership and innovative work behavior [37]. Especially, empowerment can facilitate transformational leaders to contribute and encourage their followers to achieve the organizational goals through innovative behavior. Thus, we proposed the following hypothesis shown in Figure 1:

H9. Empowerment positively moderates the relationship between transformational leadership and employees' innovative work behavior.

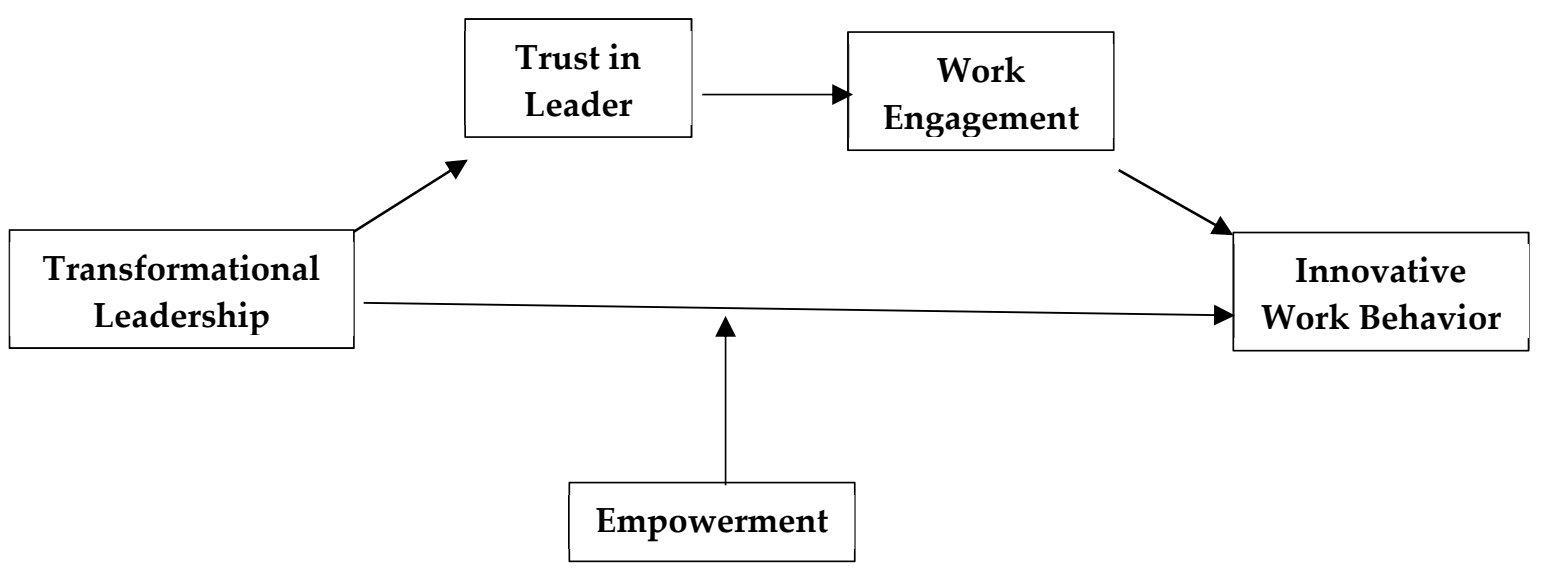

Figure 1. Hypothetical Framework. 


\section{Research Methodology}

\subsection{Procedure}

The data were collected from full-time employees engaged in multinational organizations operating in the pharmaceutical, electronics, and automobile manufacturing industry in different regions of China. The original questionnaire was developed in English and later translated into Chinese and then back into English by two bilingual experts to check the accuracy [123]. The questionnaires were distributed in two different waves, and enough time was given to the participant to fill out the questionnaire survey and return it to the research teams. In the first wave, they answered the questions regarding transformational leadership, trust in a leader, and their demographics. After two weeks, in the second wave, they rated their work engagement, empowerment, and innovative work behavior. Questionnaires in both waves were coded to validate that the responses could be matched. Respondents were assured that all of the responses would remain anonymous and only used in research. A total of 400 questionnaires was distributed, and 281 complete questionnaires were returned. The response rate was $70 \%$. In this study, $73 \%$ of respondents were male, while $66 \%$ were aged between $18-30$ years old. Almost half (47.6\%) of employees were engaged with the organization for between one and five years.

All the variables in this research were measured using a five-point Likert scale ranging from $1=$ strongly disagree to $5=$ strongly agree, except for the questions addressing transformational leadership and work engagement, which ranged from $1=$ never to $5=$ always.

\subsection{Transformational Leadership}

Transformational leadership was measured using 12-items of the Multifactor Leadership Questionnaire (MLQ) developed by [34,124], which is based on employees' perception of their supervisor's behavior. Four dimensions of transformational leadership were included: charisma, inspirational motivation, intellectual stimulation, individualized consideration. Sample items included idealized influence ("My supervisor talks about his/her most important values"), individualized consideration ("My supervisor treats me as an individual rather than just as a member of a group"), intellectual stimulation ("My supervisor suggests new ways of looking at how to complete an assignment"), and inspirational motivation ("My supervisor talks enthusiastically about what needs to be accomplished"). Cronbach's alpha for this cumulative scale was 0.88 . The average variance extracted (AVE) and composite reliability (CR) values were 0.58 and 0.84 respectively, and the factor loadings of the 11 items were higher than 0.70 , presenting a greater level of both convergent validity and internal reliability for the measure [125].

\subsection{Trust in Leader}

Employees' trust in their leader was measured using a seven-item scale developed by [126]. One sample item included, "I believe my leader has high integrity". The Cronbach's alpha for this scale was 0.84 , the AVE and CR values were 0.66 and 0.92 respectively, and the loadings of the seven items were higher than 0.73 , presenting a greater level of both convergent validity and internal reliability.

\subsection{Work Engagement}

Work engagement was measured using a nine-item Utrecht Work Engagement Scale (UWES) developed by [127]. Three dimensions of UWES were contained three items each related to vigor "At my job, I feel strong and vigorous", dedication "I am enthusiastic about my work", and absorption ("I get carried away by my work"). The Cronbach's alpha for this cumulative scale was 0.91, the AVE and $C R$ value were 0.65 and 0.86 , respectively, and the loadings of the eight items were higher than 0.78 , presenting a greater level of both convergent validity and internal reliability for the measure. 


\subsection{Empowerment}

Employee empowerment was measured using a six-item scale adapted from [128]. Sample items included in this scale were, "I feel competent to perform tasks required for my position", "I have the authority to make decisions that need to be made", and "I am confident about my capabilities and skills to excel in my job". The Cronbach's alpha for this scale was 0.90 , the AVE and CR values were 0.61 and 0.81 , respectively, and the factor loadings of the six items were higher than 0.73 , presenting a greater level of both convergent validity and internal reliability for the measure.

\subsection{Innovative Work Behavior (IWB)}

The innovative work behavior (IWB) of an individual employee was measured using a six-item scale developed by [19], which has been extensively used in the previous research studies [129-131]. Sample items included, "This employee creates new ideas for difficult issues". The Cronbach's alpha for this scale was 0.83 , the AVE and CR value were 0.75 and 0.91 , respectively, and the loadings of the six items were higher than 0.81 , presenting a greater level of both convergent validity and internal reliability.

\subsection{Control Variables}

Based on some previous studies, we included some control variables, which included gender, age, tenure with the organization, and power distance. Gender was coded male $=1$ and female $=2$, while age $(1=18-30,2=31-40,3=41-50,4=46-55,5=56$ years old and above) and tenure ( $1=1-5$ years, $2=6-10$ years, $3=11-15$ years, $4=16-20$ years) had larger ranges. Past studies have revealed individual-level cultural values impact individual responses to different aspects of their working environment, including leaders' behavior; the power distance orientation of subordinates was controlled for using a five-item scale adopted from [132]. This permits us to examine the influence of transformational leadership on employees' innovative work behavior while excluding the impact of cultural differences between employees concerning how they perceive the influence of hierarchy within the organization. Furthermore, Cronbach's alpha for this scale was 0.87 . The means that the standard deviation and correlations for all variables are presented in Table 1.

Table 1. Descriptive statistics and correlation coefficients amongst study variables $(\mathrm{N}=281)$.

\begin{tabular}{|c|c|c|c|c|c|c|c|c|}
\hline Variable & $\mathbf{M}$ & SD & 1 & 2 & 3 & 4 & 5 & 6 \\
\hline $\begin{array}{l}\text { Transformational } \\
\text { Leadership }\end{array}$ & 3.30 & 0.87 & $(0.88)$ & & & & & \\
\hline Trust in Leader & 3.82 & 0.78 & $0.530 * *$ & (0.84) & & & & \\
\hline Empowerment & 3.26 & 0.90 & $0.358^{* *}$ & $0.394^{* *}$ & $(0.90)$ & & & \\
\hline Work Engagement & 3.34 & 0.81 & $0.274^{*}$ & $0.515^{* *}$ & $0.539 * *$ & $(0.91)$ & & \\
\hline Innovative Work Behavior & 4.01 & 0.81 & 0.393 ** & $0.281^{* *}$ & $0.336 * *$ & $0.434^{* *}$ & $(0.83)$ & \\
\hline Power Distance & 3.07 & 0.70 & $0.412 * *$ & $0.375^{* *}$ & $0.391 * *$ & $0.516^{* *}$ & 0.190 & $(0.87)$ \\
\hline
\end{tabular}

\subsection{Confirmatory Factor Analysis}

Confirmatory factor analysis (CFA) in AMOS 22 was utilized [133] to check the validity and reliability of the study variables and test for common method bias [134], and we established the validity and reliability. Additionally, four alternate models were tested, which revealed that the five-factor baseline hypothesized model provide the best model fit (Table 2). Moreover, no issue was reported with discriminant validity. The confirmatory factor analysis shows that the five-factor model in this study (transformational leadership, trust in leader, work engagement, empowerment, and innovative work behavior) fit the data extremely well $\left(x^{2}=512.08\right.$, root mean square error of approximation $($ RMSEA $)=0.043$, goodness fit index $(\mathrm{GFI})=0.93$, incremental fit index $(\mathrm{IFI})=0.96$, comparative fit index $(\mathrm{CFI})=0.96$, Tucker-Lewis index $(\mathrm{TLI})=0.94)$, and it was particularly superior to the one-factor model $\left(x^{2}=1301.27, \mathrm{RMSEA}=0.127, \mathrm{GFI}=0.79, \mathrm{IFI}=0.87, \mathrm{CFI}=0.87, \mathrm{TLI}=0.82\right)$, also 
indicating that the common method bias was not a key issue in the present research. The findings of this study also support that the model fits well on all measures and it satisfies the basic requirements.

Table 2. Comparison of Measurement Models.

\begin{tabular}{|c|c|c|c|c|c|c|c|}
\hline Model-Variables & $x^{2}$ & $d f$ & GFI & IFI & CFI & TLI & RMSEA \\
\hline Five factors (baseline model) & $512.08 * * *$ & 309 & 0.93 & 0.96 & 0.96 & 0.94 & 0.043 \\
\hline $\begin{array}{l}\text { Four-factor model (work engagement and } \\
\text { innovative work behavior merged into } \\
\text { one factor) }\end{array}$ & $736.45^{* * *}$ & 328 & 0.81 & 0.89 & 0.89 & 0.81 & 0.097 \\
\hline $\begin{array}{l}\text { Three-factor model (transformational } \\
\text { leadership, trust in leader, and work } \\
\text { engagement merged into one factor) }\end{array}$ & $799.87 * * *$ & 330 & 0.88 & 0.81 & 0.80 & 0.79 & 0.073 \\
\hline $\begin{array}{l}\text { Two-factor model (transformational } \\
\text { leadership, trust, empowerment, and } \\
\text { work engagement merged into one factor) }\end{array}$ & $842.33^{* * *}$ & 332 & 0.83 & 0.85 & 0.84 & 0.81 & 0.088 \\
\hline One factor model & $1301.27 * * *$ & 338 & 0.79 & 0.87 & 0.87 & 0.82 & 0.127 \\
\hline
\end{tabular}

Note. $\mathbf{N}=281^{* * *} p<0.001$. RMSEA = root mean square error of approximation. TLI = Tucker-Lewis index.

CFI = comparative fit index. GFI = goodness fit index. IFI = incremental fit index.

\subsection{Hypotheses Testing}

This research examined the influence of transformational leadership on employees' innovative work behavior through trust in leader and work engagement. The sequence of hypothesized relationships demonstrated a serial mediation mechanism. Therefore, we used SPSS macro process [135] to test the serial mediation (Table 3) and moderation by representing transformational leadership as an independent variable, trust in a leader and work engagement as mediating variables, and innovative work behavior as a dependent variable. Furthermore, we run the bootstrapping to test the mediation on 1000 bootstrapping samples with a 95\% confidence interval (CI) suggested by Preacher and Hayes [136]. The findings revealed that transformational leadership is positively related to the trust in a leader $(\beta=0.463, p<0.000)$. This supported hypothesis H1. Trust in a leader is positively and significantly related to work engagement $(\beta=0.154, p<0.05)$, supporting hypothesis H2. Similarly, work engagement is positively associated with innovative work behavior $(\beta=0.657$, $p<0.000)$. Thus, hypothesis $\mathrm{H} 3$ was also supported. The results also revealed a positive and significant relationship of transformational leadership with employee's innovative behavior $(\beta=0.242, p<0.01)$, supporting hypothesis $\mathrm{H} 4$.

Further, the statistical results also supported the significant mediating effect of trust in a leader between transformational leadership and innovative work behavior $(\beta=0.072)$. Thus, hypothesis H5 was also supported. Consistently, the indirect effect of transformational leadership on innovative work behavior through work engagement was also significant $(\beta=0.231)$, which supports hypothesis H6. The findings also revealed a significant indirect effect of trust in a leader on innovative work behavior through work engagement $(\beta=0.182)$, which supports hypothesis H7. Finally, the findings provided statistical support for the serial mediating effect of transformational leadership on innovative work behavior through trust in a leader, and work engagement was also found to be significant ( $\beta=0.047$ ). Thus, hypothesis H8 was also supported. 
Table 3. Statistical Results of Serial Mediation Analysis for Indirect Effect of Transformational Leadership on Innovative Work Behavior through Trust and Work Engagement.

\begin{tabular}{cccc}
\hline & Model 1: DV = Trust & Model 2: DV = WE & Model 3: DV = IWB \\
\hline Gender & $0.073(0.050)$ & $0.019(0.042)$ & $0.131(0.049)^{* *}$ \\
\hline Age & $0.105(0.082)$ & $0.188(0.068)^{* *}$ & $0.184(0.081)^{*}$ \\
\hline Tenure & $0.035(0.036)$ & $-0.016(0.030)$ & $0.015(0.035)$ \\
\hline TL & $0.463(0.071)^{* * *}$ & $0.352(0.065)^{* * *}$ & $0.242(0.078)^{* *}$ \\
\hline Trust & - & $0.154(0.061)^{*}$ & $0.156(0.072)^{*}$ \\
\hline WE & - & - & $0.657(0.086)^{* * *}$ \\
\hline R-square & 0.215 & 0.301 & 0.401 \\
\hline
\end{tabular}

Indirect effect 1: TLM -> Trust $->$ IWBM $=\mathbf{0 . 0 7 2}(\mathbf{0 . 0 3 4 )}$
Significant Mediation with Upper-Bound Confidence Interval $=0.0085$ and Lower-Bound Confidence Interval $=0.1435$

Indirect effect 2: TLM $->$ Engagement $->$ IWBM $=\mathbf{0 . 2 3 1} \mathbf{( 0 . 0 5 1 )}$
Significant Mediation with Upper-Bound Confidence Interval $=0.1382$ and Lower-Bound Confidence
Interval $=0.3376$

\subsection{Moderation Results}

The statistical results of hierarchical moderation regression (Table 4) supported hypothesis H9, stating the moderation effect of empowerment on the relationship between transformation leadership and employees' innovative work behavior. Since the interaction term (TL $\mathrm{x}$ empowerment) was significant $(\beta=0.20, p<0.01)$, we plotted the slope of transformational leadership on innovative work behavior according to the follower's empowerment provided by their leaders (Figure 2). The plot explains that the relationship between transformational leadership and innovative work behavior becomes stronger at the higher level of empowerment. Thus, the results presented in Table 4 provided the support for hypothesis H9.

Table 4. Moderation Analysis for Innovative Work Behavior.

\begin{tabular}{cccc}
\hline & Model 1 & Model 2 & Model 3 \\
\hline Age & $0.105(0.082)$ & $0.159(0.071)^{* *}$ & $0.161(0.079)^{*}$ \\
Gender & $0.073(0.050)$ & $0.014(0.045)$ & $-0.110(0.057)^{* *}$ \\
Tenure & $0.035(0.0369)$ & $-0.016(0.030)$ & $0.015(0.035)$ \\
TL & & $0.194(0.0473)^{* *}$ & $0.161(0.079)^{*}$ \\
Empowerment & & $0.316(0.048)^{* * *}$ & $0.290(0.056)^{* * *}$ \\
TL x empowerment & & & $0.202(0.066)^{* *}$ \\
R-square & 0.215 & 0.284 & 0.429 \\
\hline
\end{tabular}

Note: ${ }^{*} p<0.05,{ }^{* *} p<0.01,{ }^{* * *} p<0.01$. 


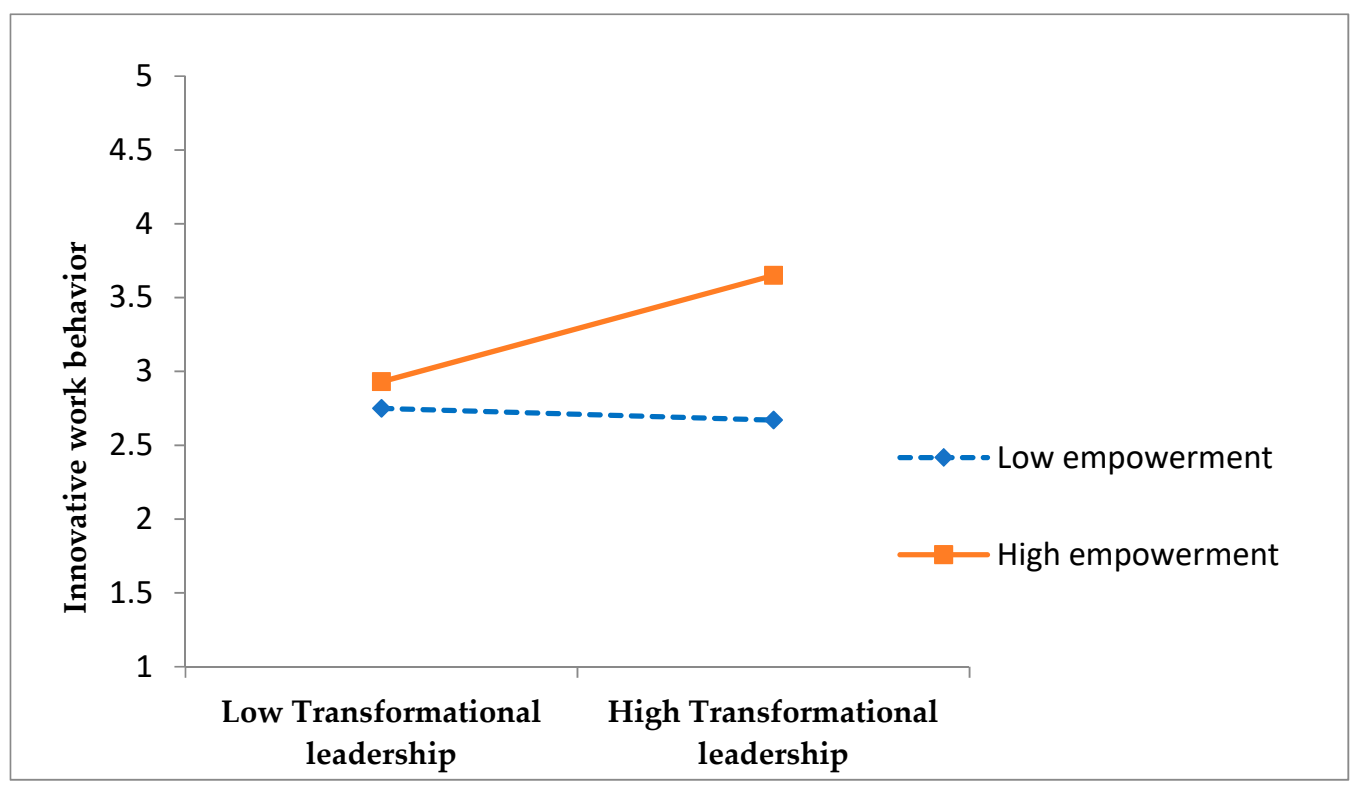

Figure 2. Interaction effect of transformational leadership and empowerment on employee's innovative work behavior.

\section{Discussion and Theoretical Contribution}

The key objective was to analyze the association between the transformational leadership, trust in leader, empowerment, work engagement, and innovative work behavior of the employees. Furthermore, we used SET to explain how the transformational leaders can positively influence the employees' innovative work behavior in the Chinese organizational context. The findings of this research revealed that the transformational leadership engenders the higher innovative work behavior of the employees through trust in leaders and work engagement. This study provides the possible understanding of hierarchy and interpersonal society for multinational organizations that are setting up their businesses in China.

The findings of this research provide empirical support for the significant role of transformational leadership in building employees' trust in a leaders, which is consistent with the findings of previous studies $[32,40,137]$. The interpersonal relationships and leader's behavior have an enormous impact on employees in the Chinese organizational context. Particularly, the leaders' ability to create and enhance employees' trust may improve organizational performance $[39,43,138]$. The significant mediating effect of trust between transformational leadership and innovative work behavior intends that trust has greater implications [139]. The employees develop more trust in leaders [140] when they observe that their leaders are caring, helpful, and fulfill their promises. Consequently, the employees' performance is improved. Thus, the characteristics of leadership have a substantial effect on the employees through boosting their trust in the leaders, which ultimately encourages them to be engaged in their work (Martins Marques de Lima Rua and Costa Araújo, 2013) [140].

Therefore, the followers of transformational leaders have greater dedication and absorption in their work [141-143]. Transformational leadership has the ability to engage employees by motivating them to stimulate their skills for organizational long-term success by exerting greater efforts [144-146]. A transformational leader has a profound emphasis on teamwork, which forms a culture where communication is open and innovations are highly commended $[80,147]$. Moreover, transformational leadership stimulates the working behavior of employees, so they dedicate their efforts to the prosperity of the organization and think outside of the box $[105,108]$. As it is proposed in the above literature, transformational leaders' behavior could affect and motivate their followers to be devoted to their work [21-23]. Moreover, transformational leaders have the ability to facilitate organizational innovation through employees' innovative behavior. Innovative work behavior can be encouraged by 
transformational leaders by engaging employees in different learning activities and enabling them to develop alternative solutions to workplace problems [27].

By investigating the influence of work engagement on innovative work behavior, this study significantly expands the knowledge that an organization can foster employee willingness to utilize their vigorous efforts and capabilities to exhibit innovative work behavior [148]. Thus, these findings are consistent with the previous studies concluding that employees with a greater level of work engagement will be expected to seek novel ideas in the organization $[23,83,149]$. Organizations that are pursuing the development of an innovative culture should do their best effort in creating and sustaining the environment that helps promote employees' innovative work behavior by emphasizing work engagement. Consequently, employee engagement positively influences an employee's innovative work behavior $[23,83,146,150]$. Transformational leaders have a greater vision in their minds for bringing out innovation in their followers at the individual level [151], which enhances organizational innovation [152].

Finally, the findings from this study also show that empowerment significantly moderates the relationship between transformational leadership and employees' innovative work behavior. Transformational leaders are also doing their best in terms of developing the followers' potential so that they become independent and able to make their own decisions $[28,153]$. Previous empirical studies revealed that transformational leadership helps employees' psychological empowerment $[154,155]$. This implies that employees are more comfortable with leaders who empower them to make their own decisions rather than just to follow their orders [36,105]. The employees perceiving a high level of empowerment will contribute more toward organizational success. Bakker et al., Laschinger et al., and Macey and Schneider [156-158] proposed that in order to increase employees' involvement in work engagement, it is compulsory to empower them. na [116].

\section{Implications for Management}

The results of the present study support the claims of SET and demonstrate the significance of transformational leadership, trust, work engagement, and empowerment for creating and enhancing employees' innovative work behavior. This research offers several implications for organizational managers. First, managers should develop transformational leadership skills to ensure more innovative outcomes for their organizations. The findings of the current study imply that employees are inspired by transformational leaders' behaviors (including the vision for an innovative organization and stimulating employees to intellectual activities), which subsequently has a positive impact on employees' innovative behavior.

Second, these results also support the view that transformational leaders may improve their relationship with employees by developing and maintaining trust. Thus, additional trainings should be provided to enhance transformational leadership behaviors [159]. Managers who are more aware of their organizational environment are more likely to gain the full advantages of leadership, because such kinds of abilities have always led them in empowering and motivating their followers [160]. The organizations must provide a secure, encouraging, and helpful working environment where employees are not scared to share novel ideas and suggestions with their leaders. An effective working environment where employees can express their suggestions, share excellent experiences, identify mistakes, share knowledge, and discuss work-based problems with their leaders is likely to exhibit a higher level of innovative work behavior (McGuire and Kennerly, 2006).

Finally, work engagement cannot exist in any organization in the absence of trust in leaders and empowerment. The organizations may develop strategies to promote employees' level of trust to benefit from work engagement. This may also facilitate employees with a greater level of trust to engage more in their work, which consecutively stimulates greater sustainable organizational performance $[157,158,161]$. In order to develop and maintain trust, the workgroup should be monitored regularly. The organizations may also cultivate trust by creating empathy and effective communication channels for employees [162]. The leaders may boost employees' innovative work 
behavior by providing an effective workplace environment that stimulates willingness to engage in their work. Consequently, employee's personal engagement, positive emotions, and vigor may contribute positively to organizational success $[55,100,163,164]$.

\section{Limitations and Future Directions}

Before analyzing possible directions for future research, it is imperative to put attention toward the limitations related to this research. First, cross-sectional data was used; thus, it's difficult to analyze the causal relation between variables. One example is whether subordinates who have more trust in their leader and empowerment can evaluate the transformational leadership characteristics more positively. This issue can be overcome by collecting longitudinal data, which can provide more applicable findings [165]. Secondly, the quantitative data that was used in this research can reveal the relationship between different variables, but cannot explain why such an association exists $[166,167]$. Moreover, qualitative data can be used in future studies to find out such a relationship. Subsequently, the mixed method (qualitative and quantitative data) can bring a broader examination of employees' innovative work.

In this study, data were collected from diverse multinational organizations operating in China. Thus, future research should be conducted in larger organizations within the national and international context with a greater sample size to generalize the results. Moreover, the empirical model used in this study is suitable and reliable. In future research, different variables that may have a leading influence on an individual's capability to exhibit creativity (e.g., LMX, voice behavior, power distance, and knowledge sharing) may be included as potential mediators. Further, in future investigations, the researchers may collect data from larger organizations serving in diverse sectors (banking, healthcare, telecommunication, manufacturing, hospitality, and information technology) to contrast the current findings. It would be more exciting to analyze whether our results are reproducible in individualistic cultures as compared to collectivistic cultures where social relationships are not crucial toward organizational success. Finally, SET was used in this study to describe the conceptual framework, but this theory was formulated in the West. The existing research is really concerned about the issues; however, it is uncertain whether theories that were developed in the Western culture could be appropriate in an Asian organizational context. Even though SET has been broadly used in Asian cultural contexts, and it is believed that it would not affect the results of this study.

Author Contributions: Data curation, H.L.; Methodology, N.S.; Formal analysis, A.M.A.; Funding acquisition, Q.W.; Investigation, N.S. and S.A.; Resources, H.L.; Software, A.M.A.; Supervision, Q.W.; Writing一 original draft, N.S.; Writing-review \& editing, Z.K. and H.L.

Funding: This research was funded by National Social Science Fund of China, grant number: No-18BGL129 and Scientific Research Fund for Universities by Chinese Ministry of Education, grant number: (2018B30214 \& 2018B47914); (2018B30214 \& 2018B47914).

Acknowledgments: The authors are thankful to the editor and anonymous reviewers for their constructive feedback and helpful suggestions.

Conflicts of Interest: The authors declare no conflict of interest.

\section{References}

1. Di Fabio, A.; Peiró, J. Human capital sustainability leadership to promote sustainable development and healthy organizations: A new scale. Sustainability 2018, 10, 2413. [CrossRef]

2. Florea, L.; Cheung, Y.H.; Herndon, N.C. For all good reasons: Role of values in organizational sustainability. J. Bus. Ethics 2013, 114, 393-408. [CrossRef]

3. Spreitzer, G.; Porath, C.L.; Gibson, C.B. Toward human sustainability: How to enable more thriving at work. Organ. Dyn. 2012, 41, 155-162. [CrossRef]

4. Martins, E.; Terblanche, F. Building organisational culture that stimulates creativity and innovation. Eur. J. Innov. Manag. 2003, 6, 64-74. [CrossRef] 
5. Schermuly, C.C.; Meyer, B.; Dämmer, L. Leader-member exchange and innovative behavior. J. Pers. Psychol. 2013, 12, 132-142. [CrossRef]

6. Imran, R.; Anis-ul-Haque, M. Mediating effect of organizational climate between transformational leadership and innovative work behaviour. Pak. J. Psychol. Res. 2011, 26, 183-199.

7. Lee, C.; Wong, C.-S. The effect of team emotional intelligence on team process and effectiveness. J. Manag. Organ. 2017. [CrossRef]

8. Chowhan, J.; Pries, F.; Mann, S. Persistent innovation and the role of human resource management practices, work organization, and strategy. J. Manag. Organ. 2017, 23, 456-471. [CrossRef]

9. $\mathrm{Hu}, \mathrm{N}$.; $\mathrm{Wu}, \mathrm{J} . ; \mathrm{Gu}, \mathrm{J}$. Cultural intelligence and employees' creative performance: The moderating role of team conflict in interorganizational teams. J. Manag. Organ. 2017. [CrossRef]

10. Javed, B.; Abdullah, I.; Zaffar, M.A.; ul Haque, A.; Rubab, U. Inclusive leadership and innovative work behavior: The role of psychological empowerment. J. Manag. Organ. 2018. [CrossRef]

11. Shalley, C.E.; Gilson, L.L. What leaders need to know: A review of social and contextual factors that can foster or hinder creativity. Leadersh. Q. 2004, 15, 33-53. [CrossRef]

12. Janssen, O. Job demands, perceptions of effort-reward fairness and innovative work behaviour. J. Occup. Organ. Psychol. 2000, 73, 287-302. [CrossRef]

13. Javed, B.; Naqvi, S.M.M.R.; Khan, A.K.; Arjoon, S.; Tayyeb, H.H. Impact of inclusive leadership on innovative work behavior: The role of psychological safety. J. Manag. Organ. 2017. [CrossRef]

14. Nazir, S.; Qun, W.; Hui, L.; Shafi, A. Influence of Social Exchange Relationships on Affective Commitment and Innovative Behavior: Role of Perceived Organizational Support. Sustainability 2018, 10, 4418. [CrossRef]

15. Nazir, S.; Qun, W.; Atif, M.M.S.; Abdullah, S.M. How organization justice and perceived organizational support facilitate employees' innovative behavior at work. Empl. Relat. 2018. [CrossRef]

16. Young, L.D. How to promote innovative behavior at work? The role of justice and support within organizations. J. Creat. Behav. 2012, 46, 220-243. [CrossRef]

17. Williams, F.; Foti, R.J. Formally developing creative leadership as a driver of organizational innovation. Adv. Dev. Hum. Resour. 2011, 13, 279-296. [CrossRef]

18. Oldham, G.R.; Cummings, A. Employee creativity: Personal and contextual factors at work. Acad. Manag. J. 1996, 39, 607-634.

19. Scott, S.G.; Bruce, R.A. Determinants of innovative behavior: A path model of individual innovation in the workplace. Acad. Manag. J. 1994, 37, 580-607.

20. Jung, D.D.; Wu, A.; Chow, C.W. Towards understanding the direct and indirect effects of CEOs' transformational leadership on firm innovation. Leadersh. Q. 2008, 19, 582-594. [CrossRef]

21. Gumusluoglu, L.; Ilsev, A. Transformational leadership, creativity, and organizational innovation. J. Bus. Res. 2009, 62, 461-473. [CrossRef]

22. Jung, D.I.; Chow, C.; Wu, A. The role of transformational leadership in enhancing organizational innovation: Hypotheses and some preliminary findings. Leadersh. Q. 2003, 14, 525-544. [CrossRef]

23. Aryee, S.; Walumbwa, F.O.; Zhou, Q.; Hartnell, C.A. Transformational leadership, innovative behavior, and task performance: Test of mediation and moderation processes. Hum. Perform. 2012, 25, 1-25. [CrossRef]

24. Bass, B.M. Leadership and Performance Beyond Expectations; Collier Macmillian: New York, NY, USA, 1985.

25. Basu, R.; Green, S.G. Leader-member exchange and transformational leadership: An empirical examination of innovative behaviors in leader-member dyads. J. Appl. Soc. Psychol. 1997, 27, 477-499. [CrossRef]

26. Conger, J.A. Charismatic and transformational leadership in organizations: An insider's perspective on these developing streams of research. Leadersh. Q. 1999, 10, 145-179. [CrossRef]

27. Choi, S.B.; Kim, K.; Ullah, S.E.; Kang, S.-W. How transformational leadership facilitates innovative behavior of Korean workers: Examining mediating and moderating processes. Pers. Rev. 2016, 45, 459-479. [CrossRef]

28. Bass, B.M. Two decades of research and development in transformational leadership. Eur. J. Work Organ. Psychol. 1999, 8, 9-32. [CrossRef]

29. Bass, B.M.; Avolio, B.J. Improving Organizational Effectiveness through Transformational Leadership; Sage Publications: Thousand Oaks, CA, USA, 1994.

30. Hartog, D.N.; Muijen, J.J.; Koopman, P.L. Transactional versus transformational leadership: An analysis of the MLQ. J. Occup. Organ. Psychol. 1997, 70, 19-34. [CrossRef] 
31. Politis, J.D. Transformational and transactional leadership enabling (disabling) knowledge acquisition of self-managed teams: The consequences for performance. Leadersh. Organ. Dev. J. 2002, 23, 186-197. [CrossRef]

32. Burke, C.S.; Sims, D.E.; Lazzara, E.H.; Salas, E. Trust in leadership: A multi-level review and integration. Leadersh. Q. 2007, 18, 606-632. [CrossRef]

33. Bass, B.M.; Avolio, B.J. Transformational leadership and organizational culture. Public Adm. Q. 1993, 17, 112-121. [CrossRef]

34. Bass, B.M.; Avolio, B.J.; Jung, D.I.; Berson, Y. Predicting unit performance by assessing transformational and transactional leadership. J. Appl. Psychol. 2003, 88, 207. [CrossRef] [PubMed]

35. Barroso Castro, C.; Villegas Perinan, M.M.; Casillas Bueno, J.C. Transformational leadership and followers' attitudes: The mediating role of psychological empowerment. Int. J. Hum. Resour. Manag. 2008, 19, 1842-1863. [CrossRef]

36. Avolio, B.J.; Zhu, W.; Koh, W.; Bhatia, P. Transformational leadership and organizational commitment: Mediating role of psychological empowerment and moderating role of structural distance. J. Organ. Behav. 2004, 25, 951-968. [CrossRef]

37. Pieterse, A.N.; Van Knippenberg, D.; Schippers, M.; Stam, D. Transformational and transactional leadership and innovative behavior: The moderating role of psychological empowerment. J. Organ. Behav. 2010, 31, 609-623. [CrossRef]

38. Slåtten, T.; Mehmetoglu, M. Antecedents and effects of engaged frontline employees: A study from the hospitality industry. Manag. Serv. Qual. Int. J. 2011, 21, 88-107. [CrossRef]

39. Schaubroeck, J.; Lam, S.S.; Peng, A.C. Cognition-based and affect-based trust as mediators of leader behavior influences on team performance. J. Appl. Psychol. 2011, 96, 863. [CrossRef] [PubMed]

40. Zhu, W.; Newman, A.; Miao, Q.; Hooke, A. Revisiting the mediating role of trust in transformational leadership effects: Do different types of trust make a difference? Leadersh. Q. 2013, 24, 94-105. [CrossRef]

41. Caldwell, C.; Dixon, R.D. Love, forgiveness, and trust: Critical values of the modern leader. J. Bus. Ethics 2010, 93, 91-101. [CrossRef]

42. Creed, D.W.; Miles, R.E. A Conceptual Framework Linking Organisational Forms, Managerial Philosophies, and the Opportunity Costs of Controls. In Trust in Organisation; Kramer, R.M., Tyler, T.R., Eds.; Sage Publications: Thousand Oaks, CA, USA, 1996.

43. Dirks, K.T.; Ferrin, D.L. Trust in leadership: Meta-analytic findings and implications for research and practice. J. Appl. Psychol. 2002, 87, 611. [CrossRef] [PubMed]

44. Yukl, G.A. An evaluation of conceptual weaknesses in transformational and charismatic leadership theories. Leadersh. Q. 1999, 10, 285-305. [CrossRef]

45. Nemanich, L.A.; Keller, R.T. Transformational leadership in an acquisition: A field study of employees. Leadersh. Q. 2007, 18, 49-68. [CrossRef]

46. Van de Ven, A.H. Central problems in the management of innovation. Manag. Sci. 1986, 32, $590-607$. [CrossRef]

47. Grant, R.M. Shifts in the world economy: The drivers of knowledge management. Knowl. Horiz. Present Promise Knowl. Manag. 2000, 27-53. [CrossRef]

48. Moss Kanter, R. When a thousand flowers bloom: Structural, collective and social conditions for innovation in organization. Knowl. Manag. Organ. Des. 1988, 10, 93-131.

49. Barron, F.; Harrington, D.M. Creativity, intelligence, and personality. Annu. Rev. Psychol. 1981, 32, 439-476. [CrossRef]

50. Blau, P.M. Justice in social exchange. Sociol. Inq. 1964, 34, 193-206. [CrossRef]

51. Organ, D.W.; Konovsky, M. Cognitive versus affective determinants of organizational citizenship behavior. J. Appl. Psychol. 1989, 74, 157. [CrossRef]

52. Gerstner, C.R.; Day, D.V. Meta-Analytic review of leader-member exchange theory: Correlates and construct issues. J. Appl. Psychol. 1997, 82, 827. [CrossRef]

53. Xerri, M.J.; Brunetto, Y. Fostering innovative behaviour: The importance of employee commitment and organisational citizenship behaviour. Int. J. Hum. Resour. Manag. 2013, 24, 3163-3177. [CrossRef]

54. Nazir, S.; Shafi, A.; Qun, W.; Nazir, N.; Tran, Q.D. Influence of organizational rewards on organizational commitment and turnover intentions. Empl. Relat. Int. J. 2016, 38, 596-619. [CrossRef] 
55. Saks, A.M. Antecedents and consequences of employee engagement. J. Manag. Psychol. 2006, 21, 600-619. [CrossRef]

56. Breevaart, K.; Bakker, A.B. Daily job demands and employee work engagement: The role of daily transformational leadership behavior. J. occup. health psychol. 2018, 23, 338-349. [CrossRef] [PubMed]

57. Gouldner, A.W. The norm of reciprocity: A preliminary statement. Am. Sociol. Rev. 1960, 25, 161-178. [CrossRef]

58. Gould-Williams, J.; Davies, F. Using social exchange theory to predict the effects of HRM practice on employee outcomes: An analysis of public sector workers. Public Manag. Rev. 2005, 7, 1-24. [CrossRef]

59. Cropanzano, R.; Mitchell, M.S. Social exchange theory: An interdisciplinary review. J. Manag. 2005, 31, 874-900. [CrossRef]

60. Molm, L.D.; Collett, J.L.; Schaefer, D.R. Building solidarity through generalized exchange: A theory of reciprocity. Am. J. Sociol. 2007, 113, 205-242. [CrossRef]

61. Lin, T.-C.; Huang, C.-C. Withholding effort in knowledge contribution: The role of social exchange and social cognitive on project teams. Inf. Manag. 2010, 47, 188-196. [CrossRef]

62. De Clercq, D.; Dimov, D.; Thongpapanl, N.T. The moderating impact of internal social exchange processes on the entrepreneurial orientation-performance relationship. J. Bus. Ventur. 2010, 25, 87-103. [CrossRef]

63. Dabos, G.E.; Rousseau, D.M. Mutuality and reciprocity in the psychological contracts of employees and employers. J. Appl. Psychol. 2004, 89, 52. [CrossRef] [PubMed]

64. Nelson, S.; Brunetto, Y.; Farr-Wharton, R.; Currant, N. The Impact of LMX on Nurses' Perceptions of Wellbeing: A Social Exchange Theory Perspective; British Academy of Management Conference: Harrogate, UK, 2008.

65. Le, P.B.; Lei, H. The mediating role of trust in stimulating the relationship between transformational leadership and knowledge sharing processes. J. Knowl. Manag. 2018, 22, 521-537. [CrossRef]

66. Harms, P.D.; Credé, M. Emotional intelligence and transformational and transactional leadership: A meta-analysis. J. Leadersh. Organ. Stud. 2010, 17, 5-17. [CrossRef]

67. Yukl, G. Managerial leadership: A review of theory and research. J. Manag. 1989, 15, 251-289. [CrossRef]

68. Podsakoff, P.M.; MacKenzie, S.B.; Moorman, R.H.; Fetter, R. Transformational leader behaviors and their effects on followers' trust in leader, satisfaction, and organizational citizenship behaviors. Leadersh. Q. 1990, 1, 107-142. [CrossRef]

69. Shamir, B.; Arthur, M.B.; House, R.J. The rhetoric of charismatic leadership: A theoretical extension, a case study, and implications for research. Leadersh. Q. 1994, 5, 25-42. [CrossRef]

70. Bligh, M.C. Leadership and trust. In Leadership Today; Springer: Berlin, Germany, 2017; pp. $21-42$.

71. Podsakoff, P.M.; MacKenzie, S.B.; Bommer, W.H. Transformational leader behaviors and substitutes for leadership as determinants of employee satisfaction, commitment, trust, and organizational citizenship behaviors. J. Manag. 1996, 22, 259-298. [CrossRef]

72. Holtz, B.C.; Harold, C.M. When your boss says no! The effects of leadership style and trust on employee reactions to managerial explanations. J. Occup. Organ. Psychol. 2008, 81,777-802. [CrossRef]

73. Lee, P.; Gillespie, N.; Mann, L.; Wearing, A. Leadership and trust: Their effect on knowledge sharing and team performance. Manag. Learn. 2010, 41, 473-491. [CrossRef]

74. Hassan, A.; Ahmed, F. Authentic leadership, trust and work engagement. Int. J. Hum. Soc. Sci. 2011, 6, 164-170.

75. Wang, B.; Qian, J.; Ou, R.; Huang, C.; Xu, B.; Xia, Y. Transformational leadership and employees' feedback seeking: The mediating role of trust in leader. Soc. Behav. Personal. Int. J. 2016, 44, 1201-1208. [CrossRef]

76. Tepper, B.J.; Dimotakis, N.; Lambert, L.S.; Koopman, J.; Matta, F.K.; Man Park, H.; Goo, W. Examining Follower Responses to Transformational Leadership from a Dynamic, Person-Environment Fit Perspective. Acad. Manag. J. 2018, 61, 1343-1368. [CrossRef]

77. Deluga, R.J. The relation between trust in the supervisor and subordinate organizational citizenship behavior. Mil. Psychol. 1995, 7, 1-16. [CrossRef]

78. Graen, G.B.; Uhl-Bien, M. Relationship-based approach to leadership: Development of leader-member exchange (LMX) theory of leadership over 25 years: Applying a multi-level multi-domain perspective. Leadersh. Q. 1995, 6, 219-247. [CrossRef]

79. Wang, H.; Law, K.S.; Hackett, R.D.; Wang, D.; Chen, Z.X. Leader-member exchange as a mediator of the relationship between transformational leadership and followers' performance and organizational citizenship behavior. Acad. Manag. J. 2005, 48, 420-432. [CrossRef] 
80. Boamah, S.A.; Laschinger, H.K.S.; Wong, C.; Clarke, S. Effect of transformational leadership on job satisfaction and patient safety outcomes. Nurs. Outlook 2018, 66, 180-189. [CrossRef] [PubMed]

81. Liu, J.; Siu, L.; Shi, K. Transformational Leadership and Employee Well Being: The Mediating Role of Trust in the Leader and Self Efficacy. Appl. Psychol. 2010, 59, 454-479. [CrossRef]

82. Luthans, F.; Peterson, S.J. Employee engagement and manager self-efficacy. J. Manag. Dev. 2002, 21, 376-387. [CrossRef]

83. Agarwal, U. Linking justice, trust and innovative work behaviour to work engagement. Pers. Rev. 2014, 43, 41-73. [CrossRef]

84. Schaufeli, W.B.; Salanova, M.; González-Romá, V.; Bakker, A.B. The measurement of engagement and burnout: A two sample confirmatory factor analytic approach. J. Happiness Stud. 2002, 3, 71-92. [CrossRef]

85. Macey, W.H.; Schneider, B.; Barbera, K.M.; Young, S.A. Employee Engagement: Tools for Analysis, Practice, and Competitive Advantage; John Wiley \& Sons: London, UK, 2011; Volume 31.

86. Shockley-Zalabak, P.; Ellis, K.; Winograd, G. Organizational trust: What it means, why it matters. Organ. Dev. J. 2000, 18, 35.

87. Van Dyne, L.; Vandewalle, D.; Kostova, T.; Latham, M.E.; Cummings, L. Collectivism, propensity to trust and self-esteem as predictors of organizational citizenship in a non-work setting. J. Organ. Behav. 2000, 21, 3-23. [CrossRef]

88. Aryee, S.; Budhwar, P.S.; Chen, Z.X. Trust as a mediator of the relationship between organizational justice and work outcomes: Test of a social exchange model. J. Organ. Behav. 2002, 23, 267-285. [CrossRef]

89. Costigan, R.D.; Iiter, S.S.; Berman, J.J. A multi-dimensional study of trust in organizations. J. Manag. Issues 1998, 10, 303-317.

90. Christian, M.S.; Garza, A.S.; Slaughter, J.E. Work engagement: A quantitative review and test of its relations with task and contextual performance. Pers. Psychol. 2011, 64, 89-136. [CrossRef]

91. Macey, W.H.; Schneider, B.; Barbera, K.M.; Young, S.A. Employee Engagement: Tools for Analysis, Practice and Competitive Advantage; Wiley-Blackwell: London, UK, 2009.

92. Asadullah, M.A.; Haider, S.; Pablos Heredero, C.D.; Musaddiq, M. Effect of ingratiation on supervisor satisfaction through helping behavior: A moderated mediation model. Intang. Cap. 2016, 12, 1157-1191. [CrossRef]

93. Chughtai, A.A.; Buckley, F. Work engagement and its relationship with state and trait trust: A conceptual analysis. J. Behav. Appl. Manag. 2008, 10, 47.

94. Lin, C.-P. Modeling corporate citizenship, organizational trust, and work engagement based on attachment theory. J. Bus. Ethics 2010, 94, 517-531. [CrossRef]

95. Smith, G.P. The New Leader: Bringing Creativity and Innovation to the Workplace; Chart Your Course Publications: Conyers, Georgia, 2002.

96. De Jong, J.P.; Den Hartog, D.N. How leaders influence employees' innovative behaviour. Eur. J. Innov. Manag. 2007, 10, 41-64. [CrossRef]

97. West, M.A.; Farr, J.L. Lnnovation and Creativity at Work: Psychological and Organizational Strategjes; John Wiley Sons: New York, NY, USA, 1990; pp. 265-267.

98. Ancona, D.G.; Caldwell, D.F. Bridging the boundary: External activity and performance in organizational teams. Adm. Sci. Q. 1992, 37, 634-665. [CrossRef]

99. Agarwal, U.A.; Datta, S.; Blake-Beard, S.; Bhargava, S. Linking LMX, innovative work behaviour and turnover intentions: The mediating role of work engagement. Career Dev. Int. 2012, 17, 208-230. [CrossRef]

100. Hakanen, J.J.; Perhoniemi, R.; Toppinen-Tanner, S. Positive gain spirals at work: From job resources to work engagement, personal initiative and work-unit innovativeness. J. Vocat. Behav. 2008, 73, 78-91. [CrossRef]

101. Dorenbosch, L.; Engen, M.L.V.; Verhagen, M. On-the-job Innovation: The Impact of Job Design and Human Resource Management through Production Ownership. Creat. Innov. Manag. 2005, 14, 129-141. [CrossRef]

102. Waldman, D.A.; Atwater, L.E. The nature of effective leadership and championing processes at different levels in a R\&D hierarchy. J. High Technol. Manag. Res. 1994, 5, 233-245.

103. Jung, D.I.; Avolio, B.J. Opening the black box: An experimental investigation of the mediating effects of trust and value congruence on transformational and transactional leadership. J. Organ. Behav. 2000, 21, 949-964. [CrossRef]

104. Felfe, J.; Goihl, K. Transformational Leadership and Commitment. Organ. Dev. Leadersh. 2002, 11, 87-124. 
105. Kark, R.; Shamir, B.; Chen, G. The Two Faces of Transformational Leadership: Empowerment and Dependency. J. Appl. Psychol. 2003, 88, 246-255. [CrossRef] [PubMed]

106. Bass, B.M.; Avolio, B.J. Full Range Leadership Development: Manual for the Multifactor Leadership Questionnaire; Mind Garden: Palo Alto, CA, USA, 1997.

107. Geyery, A.L.; Steyrer, J.M. Transformational leadership and objective performance in banks. Appl. Psychol. 1998, 47, 397-420. [CrossRef]

108. Wilson-Evered, E.; Härtel, C.; Neale, M. Leadership and innovation: Surfacing synergies among constructs and theories. In Strategy and Performance; Springer: Berlin, Germany, 2004; pp. 268-285.

109. DeGroot, T.; Kiker, D.S.; Cross, T.C. A meta-analysis to review organizational outcomes related to charismatic leadership. Can. J. Adm. Sci./Rev. Can. Des Sci. De L'administration 2000, 17, 356-372. [CrossRef]

110. Afsar, B.; Badir, Y.; Bin Saeed, B. Transformational leadership and innovative work behavior. Ind. Manag. Data Syst. 2014, 114, 1270-1300. [CrossRef]

111. Pradhan, S.; Jena, L.K. Does Meaningful Work Explains the Relationship Between Transformational Leadership and Innovative Work Behaviour? Vikalpa 2019. [CrossRef]

112. Meyerson, S.L.; Kline, T.J. Psychological and environmental empowerment: Antecedents and consequences. Leadersh. Organ. Dev. J. 2008, 29, 444-460. [CrossRef]

113. Avolio, B.J.; Walumbwa, F.O.; Weber, T.J. Leadership: Current theories, research, and future directions. Annu. Rev. Psychol. 2009, 60, 421-449. [CrossRef] [PubMed]

114. Thomas, K.W.; Velthouse, B.A. Cognitive elements of empowerment: An "interpretive" model of intrinsic task motivation. Acad. Manag. Rev. 1990, 15, 666-681.

115. Özaralli, N. Effects of transformational leadership on empowerment and team effectiveness. Leadersh. Organ. Dev. J. 2003, 24, 335-344. [CrossRef]

116. Masood, M.; Afsar, B. Transformational leadership and innovative work behavior among nursing staff. Nurs. Inq. 2017, 24, e12188. [CrossRef] [PubMed]

117. Edmondson, A.C. Speaking up in the operating room: How team leaders promote learning in interdisciplinary action teams. J. Manag. Stud. 2003, 40, 1419-1452. [CrossRef]

118. Jung, D.I.; Avolio, B.J. Effects of leadership style and followers' cultural orientation on performance in group and individual task conditions. Acad. Manag. J. 1999, 42, 208-218.

119. Parry, K.W.; Proctor-Thomson, S.B. Perceived integrity of transformational leaders in organisational settings. J. Bus. Ethics 2002, 35, 75-96. [CrossRef]

120. Delmestri, G.; Walgenbach, P. Mastering techniques or brokering knowledge? Middle managers in Germany, Great Britain and Italy. Organ. Stud. 2005, 26, 197-220. [CrossRef]

121. Zhang, A.Y.; Tsui, A.S.; Song, L.J.; Li, C.; Jia, L. How do I trust thee? The employee-organization relationship, supervisory support, and middle manager trust in the organization. Hum. Resour. Manag. 2008, 47, 111-132. [CrossRef]

122. Dutton, J.E.; Ashford, S.J.; O'neill, R.M.; Hayes, E.; Wierba, E.E. Reading the wind: How middle managers assess the context for selling issues to top managers. Strateg. Manag. J. 1997, 407-423. [CrossRef]

123. Brislin, R. Understanding Culture's Influence on Behavior; Harcourt Brace Jovanovich: San Diego, CA, USA, 1993.

124. Avolio, B.J.; Bass, B.M. MLQ: Multifactor Leadership Questionnaire; Mind Garden: Palo Alto, CA, USA, 2004.

125. Hair, J.F., Jr.; Hult, G.T.M.; Ringle, C.; Sarstedt, M. A Primer on Partial Least Squares Structural Equation Modeling (PLS-SEM); Sage Publications: Thousand Oaks, CA, USA, 2016.

126. Robinson, S.L.; Rousseau, D.M. Violating the psychological contract: Not the exception but the norm. J. Organ. Behav. 1994, 15, 245-259. [CrossRef]

127. Schaufeli, W.B.; Taris, T.W.; van Rhenen, W. Workaholism, Burnout, and Work Engagement: Three of a Kind or Three Different Kinds of Employee Well-being? Appl. Psychol. Int. Rev. 2007, 57, 173-203. [CrossRef]

128. Men, L.R.; Stacks, D.W. The impact of leadership style and employee empowerment on perceived organizational reputation. J. Commun. Manag. 2013, 17, 171-192. [CrossRef]

129. Carmeli, A.; Meitar, R.; Weisberg, J. Self-leadership skills and innovative behavior at work. Int. J. Manpow. 2006, 27, 75-90. [CrossRef]

130. Carmeli, A.; Spreitzer, G.M. Trust, connectivity, and thriving: Implications for innovative behaviors at work. J. Creat. Behav. 2009, 43, 169-191. [CrossRef]

131. Yuan, F.; Woodman, R.W. Innovative behavior in the workplace: The role of performance and image outcome expectations. Acad. Manag. J. 2010, 53, 323-342. [CrossRef] 
132. Donthu, N.; Yoo, B. Cultural influences on service quality expectations. J. Serv. Res. 1998, 1, $178-186$. [CrossRef]

133. Anderson, R.; Babin, B.; Black, W.; Hair, J. Multivariate Data Analysis-A Global Perspective; Pearson Prentice Hall: Upper Saddle River, NJ, USA, 2010.

134. Podsakoff, P.M.; MacKenzie, S.B.; Lee, J.-Y.; Podsakoff, N.P. Common method biases in behavioral research: A critical review of the literature and recommended remedies. J. Appl. Psychol. 2003, 88, 879. [CrossRef] [PubMed]

135. Hayes, A.F. Introduction to mediation, moderation, and conditional process analysis: Methodology in the Social Sciences; Guilford Publications: New York, NY, USA, 2013; p. 193.

136. Preacher, K.J.; Hayes, A.F. Asymptotic and resampling strategies for assessing and comparing indirect effects in multiple mediator models. Behav. Res. Methods 2008, 40, 879-891. [CrossRef] [PubMed]

137. Butler, J.K., Jr.; Cantrell, R.S.; Flick, R.J. Transformation leadership behaviors, upward trust, and satisfaction in self-managed work teams. Organ. Dev. J. 1999, 17, 13.

138. Yukl, G.A. Leadership in Organizations; Prentice-Hall: Upper Saddle River, NJ, USA, 2006.

139. Simpson, J.A. Psychological foundations of trust. Curr. Dir. Psychol. Sci. 2007, 16, 264-268. [CrossRef]

140. Robinson, S.L. Trust and breach of the psychological contract. Adm. Sci. Q. 1996, 41, 574-599. [CrossRef]

141. Martins Marques de Lima Rua, O.M.; Costa Araújo, J.M. The influence of the transformational leadership in the organizational trust. Harv. Deusto Bus. Res. 2013, 2, 55-66. [CrossRef]

142. Zhu, W.; Avolio, B.J.; Walumbwa, F.O. Moderating role of follower characteristics with transformational leadership and follower work engagement. Group Organ. Manag. 2009, 34, 590-619. [CrossRef]

143. Salanova, M.; Lorente, L.; Chambel, M.J.; Martínez, I.M. Linking transformational leadership to nurses' extra-role performance: The mediating role of self-efficacy and work engagement. J. Adv. Nurs. 2011, 67, 2256-2266. [CrossRef] [PubMed]

144. Tims, M.; Bakker, A.B.; Xanthopoulou, D. Do transformational leaders enhance their followers' daily work engagement? Leadersh. Q. 2011, 22, 121-131. [CrossRef]

145. Koech, P.M.; Namusonge, G. The effect of leadership styles on organizational performance at state corporations in Kenya. Int. J. Bus. Commer. 2012, 2, 1-12.

146. Pradhan, S.; Pradhan, R.K. An empirical investigation of relationship among transformational leadership, affective organizational commitment and contextual performance. Vision 2015, 19, 227-235. [CrossRef]

147. Schaufeli, W.B.; Bakker, A.B. Job demands, job resources, and their relationship with burnout and engagement: A multi-sample study. J. Organ. Behav. 2004, 25, 293-315. [CrossRef]

148. Para-González, L.; Jiménez-Jiménez, D.; Martínez-Lorente, A.R. Exploring the mediating effects between transformational leadership and organizational performance. Empl. Relat. 2018, 40, 412-432. [CrossRef]

149. Kim, W.; Park, J. Examining structural relationships between work engagement, organizational procedural justice, knowledge sharing, and innovative work behavior for sustainable organizations. Sustainability 2017, 9, 205. [CrossRef]

150. Dulaimi, M.F.; Ling, F.Y.; Bajracharya, A. Organizational motivation and inter-organizational interaction in construction innovation in Singapore. Constr. Manag. Econ. 2003, 21, 307-318. [CrossRef]

151. Bakker, A.B.; Schaufeli, W.B.; Leiter, M.P.; Taris, T.W. Work engagement: An emerging concept in occupational health psychology. Work Stress 2008, 22, 187-200. [CrossRef]

152. Damanpour, F.; Schneider, M. Phases of the adoption of innovation in organizations: Effects of environment, organization and top managers. Br. J. Manag. 2006, 17, 215-236. [CrossRef]

153. Wang, C.-J.; Tsai, H.-T.; Tsai, M.-T. Linking transformational leadership and employee creativity in the hospitality industry: The influences of creative role identity, creative self-efficacy, and job complexity. Tour. Manag. 2014, 40, 79-89. [CrossRef]

154. Bartram, T.; Casimir, G. The relationship between leadership and follower in-role performance and satisfaction with the leader: The mediating effects of empowerment and trust in the leader. Leadersh. Organ. Dev. J. 2007, 28, 4-19. [CrossRef]

155. Douglas, C.; Zivnuska, S. Developing trust in leaders: An antecedent of firm performance. Sam Adv. Manag. J. 2008, 73, 20-29.

156. Ismail, A.; Mohamed, H.A.-B.; Sulaiman, A.Z.; Mohamad, M.H.; Yusuf, M.H. An empirical study of the relationship between transformational leadership, empowerment and organizational commitment. Bus. Econ. Res. J. 2011, 2, 89. 
157. Bakker, A.B.; Albrecht, S.L.; Leiter, M.P. Key questions regarding work engagement. Eur. J. Work Organ. Psychol. 2011, 20, 4-28. [CrossRef]

158. Laschinger, H.K.S.; Wong, C.A.; Greco, P. The Impact of Staff Nurse Empowerment on Person-Job Fit and Work Engagement/Burnout. Nurs. Adm. Q. 2006, 30, 358-367. [CrossRef] [PubMed]

159. Macey, W.H.; Schneider, B. The meaning of employee engagement. Ind. Organ. Psychol. 2008, 1, 3-30. [CrossRef]

160. Dvir, T.; Eden, D.; Avolio, B.J.; Shamir, B. Impact of transformational leadership on follower development and performance: A field experiment. Acad. Manag. J. 2002, 45, 735-744.

161. Johns, G. The essential impact of context on organizational behavior. Acad. Manag. Rev. 2006, 31, 386-408. [CrossRef]

162. Schaufeli, W.B.; Salanova, M. Work engagement. Manag. Soc. Ethical Issues Organ. 2007, 135, 177.

163. Handley, K.; Sturdy, A.; Fincham, R.; Clark, T. Within and beyond communities of practice: Making sense of learning through participation, identity and practice. J. Manag. Stud. 2006, 43, 641-653. [CrossRef]

164. Bakker, A.B.; Bal, M.P. Weekly work engagement and performance: A study among starting teachers. J. Occup. Organ. Psychol. 2010, 83, 189-206. [CrossRef]

165. Salanova, M.; Schaufeli, W.B. A cross-national study of work engagement as a mediator between job resources and proactive behaviour. Int. J. Hum. Resour. Manag. 2008, 19, 116-131. [CrossRef]

166. Maxwell, S.E.; Cole, D.A. Bias in cross-sectional analyses of longitudinal mediation. Psychol. Methods 2007, 12, 23. [CrossRef] [PubMed]

167. Denzin, N.K.; Lincoln, Y.S.; Smith, L.T. Handbook of Critical and Indigenous Methodologies; Sage: Thousand Oaks, CA, USA, 2008.

(C) 2019 by the authors. Licensee MDPI, Basel, Switzerland. This article is an open access article distributed under the terms and conditions of the Creative Commons Attribution (CC BY) license (http:/ / creativecommons.org/licenses/by/4.0/). 